\title{
IbM STABILISASI PADA ATLET TINJU SULSEL MAJU (PERSIAPAN PRAPON) SULAWESI SELATAN
}

\author{
Joni Muis \\ UPP PGSD Parepare Fakultas Ilmu Pendidikan UNM \\ joni_muis@yahoo.co.id
}

\begin{abstract}
Abstrak
IbMStabilisasi Pada Atlet Tinju Sulsel Maju (Persiapan Pra-PON) Sulawesi Selatan.Tujuan dari pelaksanaan kegiatan pengabdian ini adalah untuk meningkatkan kemampuan koordinasi, kekuatan dan kelentukan dalam melontarkan pukulan pada cabang olahraga tinju. Identifikasi kebutuhanan pelatihan adalah meneliti adanya kekurangankemampuan, kondisi fisik khususnya kekuatan, kelentukan dan koordinasi gerak dan sikap pada seseorang yang dikaitkan dengan pergerakan yang akan dilakukan oleh atlet. semua kekurangan-kekuranganini dapat diatasi dengan pelatihan akan tetapi tetap diharapkan sebuah pelatihan dapat memberi nuansa dan wawasan yang benar serta tambahan pengetahuan yang menunjang segala aktivitas gerak atlet yang efektif dan efesien.Upaya mengatasi permasalahan yang ditempuh sebagai berikut.Observasi awal atau orientasi lapangan mengenai masalah-masalah yang dihadapi oleh pelatih dalam mengatasi peningkatan unsur kondisi fisik, Memberikan pemahaman tentang jenis pelatihan stabilisasi, Materi latihan, Mengadakan evaluasi, guna mengetahui kemampuan atlet dalam mencapai unsur kondisi fisik yang diharapkan guna peningkatan kekuatan, kelentukan dan koordinasi.
\end{abstract}

Kata Kunci : Latihan Stabilisasi, Persiapan Prapon

\section{Abstract}

IBM Stabilization Boxing In South Sulawesi Athletes Forward (Preparation Pra-PON) of South Sulawesi. The purpose of the implementation of service activities is to improve coordination, strength and flexibility in the throws punches in the sport of boxing. Identification of training needs is to examine the lack of ability, physical condition, especially thestrength, flexibility and coordination of movement and attitude in someone who is associated with the movement to be performed by the athletes. All of these deficiencies can be overcome by training but still expected a training can provide the right nuance and insight as well as additional knowledge of motion activities that support all athletes who are effective and efficient. Efforts to tackle the issues pursued as follows. Preliminary observations or field orientation on the problems faced by coaches to cope with increasingly an element of physical condition, provide an understanding of the types of stabilization training, exercise material, Conducting evaluations, in order to determine the ability of athletes to achieve the expected elements of the physical condition in order to improve strength, flexibility and coordination.

Keyword: Stabilization Boxing, Preparation Pra-PON

\section{PENDAHULUAN}

Program Pembinaan Sulawesi Selatan Maju. Merupakan wadah pembinaan cabang olahraga sebagai program unggulan olahraga yang dibentuk oleh pemerintah provinsi dalam rangka mengembangkan cabang-cabang 
olahraga yang mendapat prioritas dan penyumbang medali dalam event-event akbardi Indonesia seperti PON. Tujuan membentuk program Sul-Sel Maju, adalah meningkafkanprestasi atlet untuk mewujudkan target perbaikan peringkat Sulsel dari posisi ke enam pada PON 2008 di Kaltim ke urutan yang lebih baik

Data yang diperoleh dari KONI Sulsel, cabang olahraga yang ada atletnya masuk Program Pembinaan Sulawesi Selatan Maju itu antara lain senam dan renang, pencak silat, panjat dinding, selancar angin, karate, dayung, judo, balap sepeda, anggar, tinju, angkat besi, atletik, balap motor, bulu tangkis, voli pantai, loncat indab taekwondo, tenis, tenis meja, dan wushu. Untuk cabang olahraga tinju merekrut atlet sejumlah 12 orang.Program pembinaan atlet ini merupakan atlet yang terjaring dalam kejuaran nasional, PORDA dan atlet yang dibina di Pelatnas dengan potensi fisik yang telah ditentukan oleh KONI Sulawesi Selatan. Kini orang sudah mulai berbicara tentang pentingnya suatu program pembinaan modern yang professional dengan jangka waktu panjang dan berjenjang seperti yang digariskan dalam Program Sulsel Maju. Perubahan ini mengikis mindset lama yang dikungkung oleh cara instant dalam pembinaan peningkatan pr€stasi. Pemikiran tentang juara tidak dilahirkan namun dibentuk dengan program modern melalui proses berjenjang dan panjang secara perlahan namun pasti mulai berhembus di kancah olahraga nasional.

Secara keseluruhan Program Sulsel Maju memang bukan hanya urusan prestasi namun juga masa depan yang berujung pada keagungan atau kegemilangan olahraga. Pada umumnya atlet yang tergabung dalam progam ini masih memiliki banyak kekurangan utama pada penguasaan gerak dan koordinasi anggota tubuh dalam melontarkan pukulan. Tentunya kemampuan penguasaan koordinasi akan sangat mempengaruhi koordinasi gerakan yang akan dilakukan oleh kerja otot dan tendon (motorik kasar)yang terlatih, serta kekuatan fungsi indra peraba yang didukung pula oleh kemampuan visual yang baik lewat koordinasi gerakan yang sempuma

Namun lemahnya koordinasi gerakan menyebabkan atlet sulit untuk melakukan berbagai hal khususnya teknik melontarkan pukulan. Padahal pada dasarnya, koordinasi tubuh merupalan dasar kemampuan untuk bergerak. Contohnya; untuk mengangkat tangan, seorang atlet harus memiliki pengetahuan tentang tangan,selain harus pula mempunyai otot tangan yang kuat untuk menggerakkannya. Di samping itu, koordinasi tubuh yang baik akan monrmjang pula perkembangan berimajinasi atlet. Hal penting lainnya yang harus diperhatikan adalah, bahwa kedua kemanrpuan tersebut di atas, yaitu koordinasi tubuh dan koordinasi tunglai, merupakan syarat dasar untuk melatih perspektif depan-belakang, yang dapat membangun kejelian atlet dalam melahirkan teknik dasar pukulan tinju dengan benar.

\section{PERMASALAHAN MITRA}

Identifikasi kebutuhanan pelatihan adalah meneliti adanya kekurangan kemampuan, kondisi fisik khususnya kekuatan, kelentukan dan koordinasi gerak dan sikap pada seseorang yang dikaitkan dengan pergerakan yang akan dilakukan oleh atlet. semua kekurangankekurangan ini dapat diatasi dengan pelatihan akan tetapi tetap diharapkan sebuah pelatihan dapat memberi nuansa dan wawasan yang benar serta tambahan pengetahuan yang menunjang segala aktivitas gerak atlet yang efektif dan efesien.

Berdasarkan hal tersebut maka dapat dirumuskan bahwa tingkat kemampuan unsur kondisi fisik pada khususnya kekuatan, kelentukan dan koordinasi gerak atlet Program Sulsel Maju masih sangat kurang.

SOLUSI YANG DITAWARKAN DAN LUARAN

Pelaksanaan pelatihan ini digunakan metode observasi, dan demonstrasi langsung 
dan dilengkapi dengan beberapa metode antara lain : praktek dan evaluasi hasil latihan. Kegiatan dalam pelatihan ini antara lain: 1) Observasi, yaitu mengadakan orientasi terhadap permasalahan-permasalahan yang dihadapi oleh atlet yang menjadi sasaran pelaksanaan kegiatan ini. 2) Demonstrasi, memberikan praktek langsung pada atlet khususnya dalam meningkatkan unsur kondisi fisik yaitu kekuatan, kelentukan dan koordinasi. Upaya mengatasi permasalahan yang dikemukakan di atas, maka alternatif pemecahan yang akan ditempuh sebagai berikut. 1) Mengadakan observasi awal atau orientasi lapangan mengenai masalah-masalah yang dihadapi oleh pelatih dalam mengatasi peningkatan unsur kondisi fisik. 2) Memberikan pemahaman tentang jenis pelatihan stabilisasi. 3) Mengadakan evaluasi, guna mengetahui kemampuan atlet dalam mencapai unsur kondisi fisik yang diharapkan guna peningkatan kekuatan, kelentukan dan koordinasi.

Adapun target luaran yang ingin dicapai dalam pelatihan ini adalah : 1) Untuk meningkatkan kemampuan koordinasi gerak, kelentukan dan kekuatan dalam melontarkan pukulan. 2) Untuk memaksimalkan program latihan yang diberikan oleh pelatih kepada atlet agar kemampuan kondisi fisik menjadi lebih baik. 3) Memaksimalkan persiapan atlet dalam menghadapi PraPON dan kesiapan peserta dalam program pembinaan Sulsel Maju. Setelah mengikuti pelatihan ini atlet mampu menambah pengetahuan dan meningkatkan unsur kondisi fisik demi tercapainya sebuah tujuan yang telah disusun dalam pelatihan ini. Setelah kegiatan ini selesai maka para peserta pelatihan dan pelatih dapat membangun sebuah kesamaan visi dalam berlatih dan mampu melakukan koordinasi gerakan dengan baik dan mempunyai unsur fisik yaitu kekuatan dan kelentukan yang baik.

\section{KELAYAKAN PERGURUAN TINGGI}

Dalam pelaksanaan kegiatan pelatihan stabilisasi untuk atlet ini, dilaksanakan oleh dua orang dimana satu orang bertindak sebagai ketua tim pelaksana dan satu orang bertindak sebagai anggota tim pelaksana. Adapun pembagian kerja dari tim pelaksana adalah ketua tim pelaksana mendapatkan waktu pengajaran selama 24 jam sementara untuk anggota tim pelaksana masing-masing mendapatkan waktu mengajar selama 15 jam.Kegiatan ini berlangsung selama 4 (empat) bulan yang dilaksanakan pada Mei - Oktober 2011 bertempat di Makassar.

\section{PELAKSANAAN, PEMBAHASAN DAN MATERI KEGIATAN}

Alat yang digunakan 1) Stopwach : untuk menghitung dan mengukur kemampuan atlet dalam melaksanakan latihan dan evaluasi Zamsack : digunakan untuk mengukur tingkat kemampuan atlet dalam melontarkan pukulan, 3) LCD : untuk membantu dalam menjelaskan materi

Kegiatan pengabdian masyarakat ini dilakukan dalam bentuk pelatihan. Pelatihan tersebut menggunakan demonstrasi atau praktek langsung. Langkah-langkah yang ditempuh dalam pelatihan ini adalah : 1) Mengadakan observasi awal atau orientasi lapangan mengenai masalah-masalah yang dihadapi oleh pelatih dalam mengatasi peningkatan unsur kondisi fisik. 2) Memberikan pemahaman tentang jenis pelatihan stabilisasi. 3) Memberikan perlakuan beberapa bentuk gerakan latihan stabilisasi 4) Mengadakan evaluasi, guna mengetahui kemampuan atlet dalam mencapai unsur kondisi fisik yang diharapkan guna peningkatan kekuatan, kelentukan dan koordinasi.

Hasil evaluasi pada akhir kegiatan pengabdian pada masyarakat ini menunjukkan bahwa secara keseluruhan atlet tinju Sulsel Maju dalam melakukan koordinasi gerak 
menunjukkan perkembangan yang maksimal. Karena hasil evaluasi/tes akhir yang kami lakukan pada akhir kegiatan yaitu mengukur jumlah pukulan yang dilontarkan pada zamsack rata-rata atlet mampu melontarkan 80 - 110 pukulan dengan baik dan benar. Hal ini menunjukkan bahwa unsur kondisi fisik atlet mengalami peningkatan.

Faktor pendorong adalah adanya partisipasi aktif dari atlet tinju Sulsel Maju yang dalam mengikuti pelatihan telah meluangkan waktu secara antusias untuk mengikuti seluruh rangkaian kegiatan sehingga pada akhirnya memperlancar kegiatan ini. Selain itu atlet menunjukkan minat dan kemauan yang tinggi untuk mengikuti kegiatan ini sehingga unsur kondisi fisik yaitu koordinasi, kekuatan dan kelentukan dapat meningkatkan sesuai dengan yang diharapkan. Sedangkan faktor penghambat adalah terbatasnya waktu dari kami sebagai pemateri atau pelatih.

\section{KESIMPULAN}

Kegiatan pengabdian kepada masyarakat yang kami lakukan mendapat smbutan dan tanggapan yang positif dari Pengurus KONI Provinsi Sulawesi Selatan dan atlet dalam program pembinaan Sulsel Maju dalam menghdapi Prapon. Hal ini terlihat pada kesungguhan dan keseriusan mereka saat pemberian materi kegiatan latihan stabilisasi. Pelatihan ini merupakan suatu kegiatan yang sangat membantu atlet dalam meningkatkan unsur kondisi fisik yaitu koordinasi, kelentukan dan kekuatan sehingga atlet mampu menjaga kestabilan fisiknya dan implementasinya peningkatan prestasi yang diharapkan.

Hendaknya pelatihan atau sosialisasi metode latihan ini dapat diterapkan dan dikembangkan sehingga latihan cukup bervariasi dan mampu mengatasi kejenuhan yang dihadapi atlet pada saat latihan

\section{DAFTAR PUSTAKA}

Ali, M. 1985. Penelitian Kependidikan "Prosedur dan Strategi". Bandung. Penerbit Angkasa

Awan, H. 2006. Metode Melatih Fisik Pencak Silat. Yogyakarta. FIK UNY

Dikdik Zafar Sidik. 2006. Preiodosasi Latihan untuk Olahraga Dominan. Jakarta. International School Jakarta.

Maksum, A. 2004. Pengkajian Sport Development Index. Jakarta. Dirjen Olahraga

Nossek. J. 1992. General Theory of Training. Logos. National Intitute for Sport.

Nala, N. 1998. Prinsip Pelatihan Fisik Olahraga. Denpasar. Program Pascasarjana Program Studi Fisiologi Olahraga Universitas Udayana.

Sadoso. 2005. Jangan Malas Berolahraga. Diambil dari. http://www.depkes.go.id 